\title{
Targeted delivery of reduced graphene oxide nanosheets using multifunctional ultrasound nanobubbles for visual and enhanced photothermal therapy [Corrigendum]
}

Liu Z, Zhang J, Tian Y, Zhang L, Han X, Wang Q, Cheng W. Int J Nanomedicine. 2018;13:7859-7872.
Page 7864, Figure 2G, the incorrect image has been used, the correct figure is shown below.
A

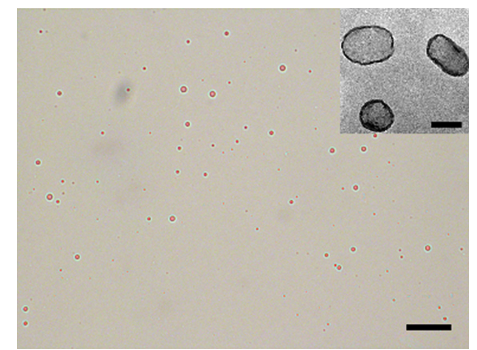

D

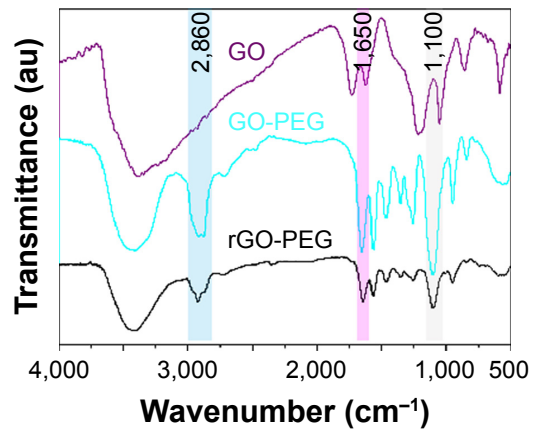

G

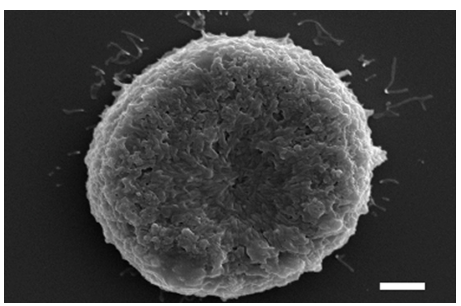

B

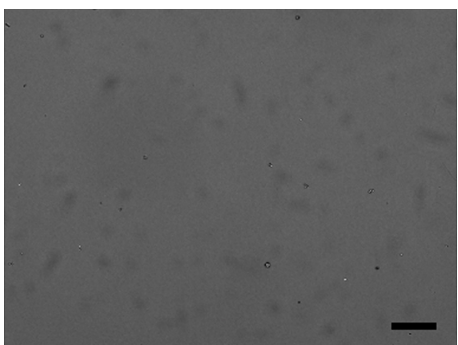

E

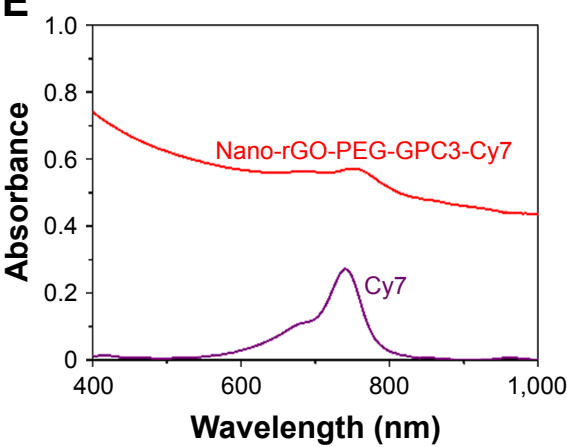

H

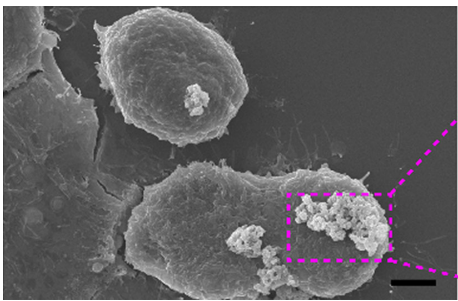

C

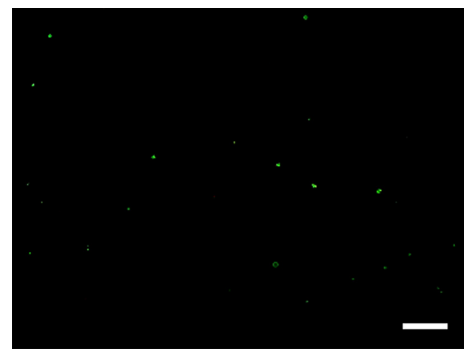

F
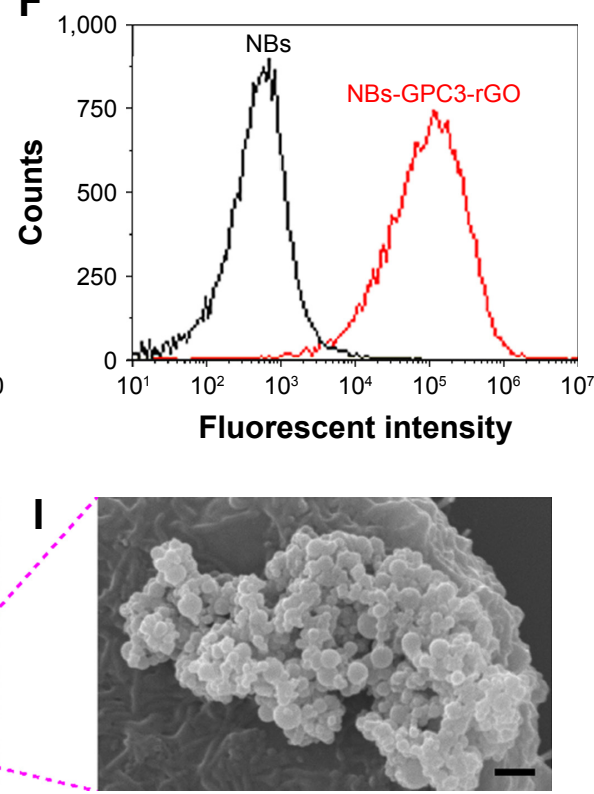

Figure 2 Characterization of nanobubbles, proof the chains are convelent together.

Notes: Bar in $\mathbf{A}-\mathbf{C}$ is $10 \mu \mathrm{m}$, inset in Figure $2 \mathrm{~A}$, bar $=100 \mathrm{~nm}$, bar in $\mathbf{G}$ and $\mathbf{H}=4 \mu \mathrm{m}$, bar in $\mathbf{I}=0.6 \mu \mathrm{m}$. (A) Nanobubbles (NBs) in suspension were milk white in color. Pure NB solution was observed under a light microscope (magnification, I,000×). (B) Avidinylated nanobubbles were observed under a light microscope (magnification, I,000 $\times$ ). (C) Nanobubbles conjugated with FITC-labeled avidin under fluorescence microscopy (magnification, I,000x). The surface of nanobubbles appeared green under fluorescence microscopy, indicating that FITC-labeled avidin was packaged on the NB surface. (D) Fourier transform infrared (FTIR) spectra of graphene oxide-polyethylene glycol (GOPEG) and reduced graphene oxide ( $\mathrm{rGO}$ )-PEG. The GO-PEG and rGO-PEG sample was filtered over three times through a $100 \mathrm{kDa}$ molecular weight cutoff (MWCO) filter to completely remove any unconjugated PEG (I0 kDa). (E) AUV-vis-near-infrared (NIR) spectrum of nano-rGO-PEG-GPC3-cy7 and free cy7 dye solution. (F) Binding efficiency of biotinylated FITC-labeled rGO-PEG-GPC3 with avidinylated NBs was determined by flow cytometry. Comparison of the fluorescence intensities for NBs (black line, control) and FITC-labeled NBs-GPC3-rGO (red line) implies successful binding of rGO-PEG-GPC3 with avidinylated NBs. (G) Scanning electron microscopy revealed normal surface morphology of the Hep G2 cells (4,000x). Under scanning electron microscopy, targeted NBs-GPC3-rGO were clustered on the surface of the Hep G2 cells ( $\mathbf{H}$ and $\mathbf{I}, 4,000 \times$ and $10,000 \times$, respectively).

Abbreviation: GPC3, heparin sulfate proteoglycan glypican-3. 


\section{Publish your work in this journal}

The International Journal of Nanomedicine is an international, peerreviewed journal focusing on the application of nanotechnology in diagnostics, therapeutics, and drug delivery systems throughout the biomedical field. This journal is indexed on PubMed Central,

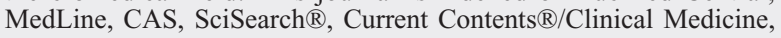

Journal Citation Reports/Science Edition, EMBase, Scopus and the Elsevier Bibliographic databases. The manuscript management system is completely online and includes a very quick and fair peer-review system, which is all easy to use. Visit http://www.dovepress.com/ testimonials.php to read real quotes from published authors.

Submit your manuscript here: http://www.dovepress.com/international-journal-of-nanomedicine-journal 